\title{
Passive Properties of Cr12Ni3Co12Mo4W Ultra-High-Strength Martensitic Stainless Steel
}

\author{
Huiyan $\mathrm{Li}^{1}$, Shiwen Zou ${ }^{2}$, Chaofang Dong ${ }^{1, *}$, Kui Xiao ${ }^{1}$, Xiaogang Li $^{1}$, Ping Zhong ${ }^{3}$ \\ ${ }^{1}$ Corrosion and Protection Center, Key Laboratory for Corrosion and Protection (MOE), University of \\ Science and Technology Beijing, Beijing 100083, China \\ ${ }^{2}$ Aerospace Research Institute of Materials \&Processing Technology, Beijing, 100076, China \\ ${ }^{3}$ Beijing Institute of Aeronautical Materials, Beijing 100095, China \\ *E-mail: cfdong@ustb.edu.cn
}

doi: $10.20964 / 2017.01 .75$

Received: 21 February 2016 / Accepted: 28 March 2016 / Published: 12 December 2016

\begin{abstract}
The passive properties of the $\mathrm{Cr} 12 \mathrm{Ni} 3 \mathrm{Co} 12 \mathrm{Mo} 4 \mathrm{~W}$ ultra-high-strength martensitic stainless steel were investigated by surface analysis techniques and electrochemical measurements. The potentiodynamic polarization curves exhibited a wide passivity region, which indicated that the ultra-high-strength martensitic stainless steel exhibited excellent electrochemical characteristics in $0.1 \mathrm{M} \mathrm{Na}_{2} \mathrm{SO}_{4}$ solution $(\mathrm{pH}=3)$. The thickness of the passive films increased from $0.7 \mathrm{~nm}$ to $5.2 \mathrm{~nm}$ with the increase of film formation potential. The passive films formed at different potentials exhibited $\mathrm{n}$ - and p-type semiconductor behaviors. The passive films formed at more positive potentials were more stable, with lower oxygen vacancy concentrations than those formed at lower potentials. The films formed at anodic potentials primarily comprised $\mathrm{FeO}, \mathrm{Fe}_{3} \mathrm{O}_{4}, \mathrm{Fe}_{2} \mathrm{O}_{3}, \mathrm{Cr}_{2} \mathrm{O}_{3}, \mathrm{Cr}(\mathrm{OH})_{3}, \mathrm{NiO}$ and $\mathrm{MoO}_{3}$. The passive films formed at anodic potentials were predominantly composed of Fe oxides, whereas those formed at cathodic potentials were primarily composed of oxides and hydroxides of $\mathrm{Cr}$. The contribution of alloy element $\mathrm{Ni}$ to the passivity performance of the steel was larger than that of Mo. During the pitting corrosion, the passive films remarkably increased the pitting potential.
\end{abstract}

Keywords: potential, passive film, ultra-high-strength martensitic stainless steel, electronic properties, XPS

\section{FULL TEXT}

(C) 2017 The Authors. Published by ESG (www.electrochemsci.org). This article is an open access article distributed under the terms and conditions of the Creative Commons Attribution license (http://creativecommons.org/licenses/by/4.0/). 